\title{
Efficiency of utilization of volatile fatty acids for maintenance and energy retention by sheep
}

\author{
BY E. R. ØRSKOV, D. A. GRUBB, J. S. SMITH, \\ A. J. F. WEBSTER* AND W. CORRIGALL \\ Rowett Research Institute, Bucksburn, Aberdeen AB2 $9 S B$ \\ (Received 31 July 1978 - Accepted 17 October 1978)
}

\begin{abstract}
I. Two experiments were conducted with lambs sustained entirely by intragastric infusion of volatile fatty acids (VFA), protein, minerals and vitamins.

2. In the first experiment to determine the effects of VFA on nitrogen retention four mixtures of VFA $(B, C, D$ and $E)$ were used containing acetic, propionic and butyric acid in the following molar proportions respectively: 45,45 and $10 ; 55,35$ and $10 ; 65,25$ and $10 ; 75, \mathrm{I} 5$ and 10 . The level of infusion was $836 \mathrm{~kJ} / \mathrm{live}$ weight $^{0.75}$ per $d$ and the design was a $4 \times 4$ Latin square with $14 \mathrm{~d}$ periods. There were no significant differences in the $\mathbf{N}$ balance between the different mixtures of VFA though mixture $\mathrm{B}$ tended to give the highest $\mathrm{N}$ retention.
\end{abstract}

3. Thirty-two lambs were used in the second experiment for measurements of heat production in closedcircuit respiration chambers. Six mixtures of VFA were used. These included mixtures B-E from Expt I and in addition two mixtures ( $A$ and $F$ ) containing acetic, propionic and butyric acid in the following molar proportions respectively: 35,55 and $10 ; 85,5$ and 10 . The heat production was measured both at 450 and $900 \mathrm{~kJ} / \mathrm{W}^{0.75}$ per $\mathrm{d}$, except for mixture $\mathrm{F}$, where it was not possible to achieve a rate of infusion in excess of $675 \mathrm{~kJ} / \mathrm{W}^{0.75}$ per $\mathrm{d}$.

4. The energy required for maintenance was determined to be $0.45 \pm 0.02 \mathrm{MJ} / \mathrm{kg}$ live weight $0^{0.75}$ per $\mathrm{d}$ regardless of the mixture used.

5. The efficiency of utilization for fattening $\left(k_{f}\right)$ values for the six mixtures were $0.78,0.64,0.57,0.61,0.61$ and 0.59 for mixtures A, B, C, D, E and F respectively. Only mixture A was significantly better utilized than the other mixtures. This mixture also gave the most efficient $\mathrm{N}$ utilization.

6. It is concluded from this evidence that differences in $k_{f}$ for diets normally given to ruminants cannot be attributed to differences in utilization of volatile fatty acids.

Volatile fatty acids (VFA), which are the end-products of anaerobic fermentation in the rumen, were first shown by Barcroft et al. (1944) to be the main source of metabolizable energy (ME) for ruminant animals. There are marked differences in the molar proportions of the major VFA, acetate, propionate and butyrate, which are produced from diets by fermentation in the rumen. The ratio, acetate:propionate tends to increase as the fibre content of the diet increases (see Annison \& Armstrong, 1970; Ørskov, 1975). It has been shown with a range of diets that there is a negative relationship between the proportion of acetic acid in rumen fluid and the efficiency of utilization of $\mathrm{ME}$ for fattening (see Blaxter, 1962). Since the acetic acid proportion generally increases with increasing dietary fibre content (see Ørskov, I975) there is also generally a decrease in efficiency of utilization of ME as the fibre content of the diet increases (see Blaxter, 1962; Daccord, I971; Lawrence \& Thomas, 1973). These observations suggested that there might be a causal relationship which could be established by measurements of the heat increment resulting from absorption of the major VFA. Such measurements were made by Armstrong \& Blaxter (1957a) and Armstrong et al. (1957), who infused VFA into the rumens of sheep as the only source of energy and measured the effect on heat production in closed-circuit respiration chambers. They concluded from this work that provided a small amount of propionic acid was present in the mixture to supply $\mathrm{C}_{3}-\mathrm{C}$ for efficient oxidation then the three major VFA acetic,

* Present address: University of Bristol, Department of Animal Husbandry, Langford, Bristol BS I 8 7DU. 0007-1145/79/3208-1710 \$01.00 (C) I979 The Nutrition Society 
propionic and butyric acids were utilized with an equal efficiency for maintenance. Their results have been confirmed in later work by Holter et al. (1970) using cows and by many indirect observations (see Blaxter, 1962) showing a relative constancy of utilization of $\mathrm{ME}$ for maintenance, though later the comprehensive analysis by Blaxter \& Boyne (1978) has shown that ME from diets varying in fibre content are utilized with slightly differing efficiencies at the maintenance energy level, i.e. that the efficiency of utilization for maintenance $\left(k_{m}\right)$ has different slopes depending on the metabolizability $(q)$ of the diet.

The utilization of VFA for growth and fattening has been more difficult to study since the VFA have usually been studied as additives to a basal diet and in general have contributed only a small proportion of the total ME. Armstrong \& Blaxter (I957 $b$ ) infused acetic, propionic and butyric acid as an increment adding approximately $15 \%$ ME to a basal diet of dried grass, and they measured by indirect calorimetry the heat increment in sheep. They observed that acetic acid was utilized with an efficiency considerably less than that of propionic and butyric acid. Later Armstrong et al. (1958) infused mixtures high or low in the proportion of acetic acid and concluded that the utilization of VFA mixtures for fattening could be predicted on the basis of direct proportionality of response to the individual acids. In this paper, however, they incorrectly predicted heat increment from molar proportions rather than from the proportions of combustible energy supplied by the three VFA (see Ørskov, 1965). Calculated from their contribution of combustible energy the high acetic acid mixture gave a heat increment significantly greater than predicted.

The results of a series of comparative slaughter experiments in which lambs were given salts of VFA as an addition to a basal diet, have been summarized by Ørskov \& Allen (I966) and they found it was not possible to demonstrate differences in utilization of salts from different VFA for carcass weight gain. There was a tendency, albeit not significant, for acetate to be utilized less efficiently when it was added to a basal diet which already gave a high acetate fermentation. Bull et al. (1970) reported that ME from triacetin was utilized with an efficiency equal to that of the ME from a basal concentrate. With dairy cows Orskov et al. (I968) found that while acetic and propionic acid gave differences in the partition of energy to milk or body tissue synthesis there was no detectable difference in the efficiency of the utilization of the energy they provided. Hovell et al. (1976) were unable to detect differences in heat production measured by indirect calorimetry when acetate salt was compared with a barley concentrate. Hovell \& Greenhalgh (1978) later showed that acetate was utilized with different efficiencies depending on the level of incorporation into a basal diet of concentrate. Tyrrell et al. (1975) similarly showed that the efficiency of utilization of acetic acid depended on the basal diet to which it was added.

The procedure of adding VFA either as acids or their salts inevitably tends to interfere with the metabolism of the basal diet to an extent which is almost impossible to assess. When salts are used there is the additional problem that more cations have to be given with acetate than when a similar amount of energy from propionate or butyrate is given. These problems were highlighted by Armstrong et al. (1958) who found a reduction in methane production when a high acetic acid mixture was used and by Tyrrell et al. (1975) who observed both a reduction in methane production and an increase in faecal energy loss.

Ørskov et al. (1978) recently developed a technique to sustain ruminants at high energy levels for long periods by infusing nutrients, chiefly VFA and protein in liquid form, into the rumen and abomasum respectively. This technique has enabled us to look again at the utilization of VFA without the problems of interference with digestion and metabolism of the basal diet.

This paper gives the results of two experiments with young sheep. In the first, the effect on nitrogen balance of varying the VFA composition of the infusate was measured. In the second, complete records of energy and $\mathrm{N}$ balance were made for lambs infused with VFA 
mixtures varying from 0.35 to 0.85 in the proportion of acetic acid and given at two levels, to provide maintenance and above.

A short account of the experiments has been published (Ørskov \& Grubb, 1977; Ørskov et al. 1978).

\section{MATERIALS AND METHODS}

Expt I

Animals. Four castrated Suffolk $\times$ (Finnish Landrace $\times$ Dorset Horn) lambs were used. They were fitted with rumen cannulas and abomasal catheters as described by Ørskov et al. (1978). After surgery they were given 2 weeks for recovery and changed gradually from a diet of dried grass to receive their nutrients by infusion. The level of infusion was calculated to contribute $836 \mathrm{~kJ} / \mathrm{W}^{0.75}$ per $\mathrm{d}$, where $\mathrm{W}$ is the live weight in $\mathrm{kg}$.

Design and treatments. A $4 \times 4$ Latin square design was used with four lambs and four periods. Four different mixtures of VFA were used containing acetic, propionic and butyric acid in the following molar proportions (mmol/mol) 450,450, 100;550, 350, $100 ; 650,250$, $100 ; 750,150$, I00 respectively. The level of infusion was reached in 3 weeks after which $\mathrm{N}$ excretion was measured for a period of $7 \mathrm{~d}$. The change-over from one type of VFA mixture to another was accomplished during $7 \mathrm{~d}$ after which the urinary $\mathrm{N}$ was again measured for a period of $7 \mathrm{~d}$. In this experiment the lambs had access to dried grass but when the desired rate of infusion was reached, little if any grass was eaten. The levels of $\mathrm{N}$ were similarly given at the estimated maintenance level $\left(0.71 \mathrm{~g} / \mathrm{W}^{0.75}\right)$ or for retention when the energy level was twice energy maintenance, ( $\left.1 \cdot 42 \mathrm{~g} / \mathrm{W}^{0 \cdot 75}\right)$.

Infusion procedure. Details of the infusion procedure are given elsewhere (Ørskov et al. 1979), briefly the VFA were infused into the rumen in 2.51 aqueous solution/d which in addition to the VFA also contained the required macrominerals. A solution of buffer based on the composition of saliva was also infused into the rumen in a 2.51 solution. The casein dissolved with $\mathrm{Na}_{2} \mathrm{CO}_{3}$ was infused into the abomasum also in a 2.51 solution. The required vitamins were added to the casein solution. The three solutions were given as a continuous infusion. The required trace minerals were injected once daily into the abomasal catheter. The proportions of VFA in the rumen were monitored on occasions and the proportion found was similar to the proportions in the infusate. The rumen $\mathrm{pH}$ was monitored twice daily and if on occasion the rumen $\mathrm{pH}$ was below $6 \cdot 0$ additional buffer was added.

\section{Expt 2}

Animals. Thirty-two castrated male lambs were used. They were of Suffolk $\times$ (Finnish Landrace $\times$ Dorset Horn) breeding, 3-4 months old, and weighed approximately $25 \mathrm{~kg}$ when they were prepared for the experiment. Each was fitted with a cannula in the rumen and a catheter in the abomasum according to the procedure described by Ørskov et al. (1979).

Design. Each lamb was given 2 weeks for recovery after surgery. They were then placed in metabolism cages which allowed for collection of faeces and urine. The mixtures of VFA were introduced and infused according to the procedure described by Ørskov et al. ( I979). Half the lambs were allocated for measurements of heat production made first at maintenance energy level $\left(450 \mathrm{~kJ} / \mathrm{W}^{0.75}\right)$ and then at twice that level $\left(900 \mathrm{~kJ} / \mathrm{W}^{0.75}\right)$; the other half had heat production measured at the same levels but in the reverse order. After successful measurements of heat production at maintenance and twice maintenance the lambs were slaughtered for post-mortem examination. As detailed by Ørskov et al. (I979) the level of infusion was increased in steps of $0.25 \times$ maintenance energy level. Each level was maintained for at least $2 \mathrm{~d}$. Consequently a period of at least $16 \mathrm{~d}$ was required to reach twice 
maintenance energy level. The measurement of heat production was made after the lambs had been at least $7 \mathrm{~d}$ on the planned level of infusion. The infusion procedure was similar to that described in Expt $I$.

Heat production. The lambs were kept in metabolism cages inside a closed-circuit respiration chamber (Wainman \& Blaxter, I969), where oxygen consumption and carbon dioxide production were measured for $2 \mathrm{~d}$. As expected there was no measurable methane production. There are several ways in which heat production can be calculated. It can be calculated from the usual formulas for $\mathrm{O}_{2}$ consumption and $\mathrm{CO}_{2}$ production corrected for the over-estimate of heat production that this would give rise to with the different VFA used, as explained by Blaxter (1962). In the short account by Ørskov et al. (1979) the heat production was calculated simply by the method of Blaxter (I962) corrected for the overestimate. It can also be calculated from $\mathrm{O}_{2}$ consumption alone. This has certain advantages in so far that a considerable amount of $\mathrm{CO}_{2}$ would arise from excretion of $\mathrm{CO}_{2}$ given via the buffer solution and which had no energy contribution. The heat production was finally calculated from the $\mathrm{O}_{2}$ consumption using the $\mathrm{O}_{2}$ consumption and the energy release from oxidation of VFA and protein essentially similar to the method adopted by Armstrong \& Blaxter ( $1957 b$ ). The amount of protein oxidized was taken to be that of the $N \times 6.25$ excreted in the urine since in any case there was no faecal $\mathrm{N}$.

$N$ excretion. $\mathrm{N}$ excretion was measured during the $2 \mathrm{~d}$ in the respiration chamber and $3 \mathrm{~d}$ before and therefore the $\mathrm{N}$ retention values were based on $5 \mathrm{~d}$ collection of urine. Since no solid food was offered there was no faeces.

Treatments. Six animals per treatment were originally allocated to the four mixtures used in Expt $\mathrm{I}$. When the initial results indicated only small differences in heat production, four animals per treatment were allocated to two additional mixtures containing acetic, propionic and butyric acid in the following molar proportions respectively: 350,550 and 100 ; 850,50 and 100. Casein was infused to give 0.71 and $\mathrm{I} \cdot 42 \mathrm{~g} \mathrm{~N} / \mathrm{W}^{0.75}$. These levels were calculated to be in excess of the $\mathrm{N}$ required for the maintenance of tissue $\mathrm{N}$ and for $\mathrm{N}$ retention (Ørskov, 1977). Maintenance energy requirement was taken to be approximately $450 \mathrm{~kJ} / \mathrm{W}^{0.75}$ (see Ørskov \& McDonald, 1970).

\section{RESULTS}

\section{Expt I}

One lamb died after having completed two periods of the experiment. It was replaced by another of similar weight which completed the last two periods. For the analysis of variance these two were treated as one animal. The results of the intake excretion and balance of $\mathrm{N}$ are given in Table $\mathrm{I}$.

The difference in intake of $\mathrm{N}$ between the casein- $\mathrm{N}$ and total $\mathrm{N}$ was due to the occasional intake of dried grass and likewise the difference between urinary $\mathrm{N}$ and total $\mathrm{N}$ excretion was due to the faecal excretion. There were no significant treatment differences in $\mathrm{N}$ balance, although Table $\mathrm{I}$ indicates that the highest $\mathrm{N}$ balance occurred with the highest proportion of propionic acid.

\section{Expt 2}

Several attempts were made to infuse VFA at twice maintenance on the highest acetic acid mixture. They were all unsuccessful and two lambs died. Post-mortem examination revealed signs of complete gut stasis which agreed with the difficulty of maintaining the $\mathrm{pH}$ at approximately $6 \cdot 5$, presumably due to lack of VFA absorption. There was also kidney failure and inflammation of the rumen wall.

Energy intakes, heat production and energy balance expressed in relation to metabolic 
Table I. The effect of varying proportions of volatile fatty acids $(V F A)$ infused into the rumen on the utilization of casein-nitrogen infused into the abomasum of lambs

(Each value is the mean of four observations)

\begin{tabular}{ccc}
\multicolumn{3}{c}{ Proportion of VFA } \\
$\overbrace{\text { Acetic }}$ & Propionic & Butyric \\
450 & 450 & 100 \\
550 & 350 & 100 \\
650 & 250 & 100 \\
750 & 150 & 100 \\
\multicolumn{3}{c}{ SE of treatment means }
\end{tabular}

$\begin{array}{cr}\text { Casein } & \text { Total } \\ 16.5 & 16.5 \\ 16.9 & 17.2 \\ 16.4 & 17.0 \\ 16.5 & 17.5 \\ 0.2 & 0.2\end{array}$

$\begin{array}{cr}\text { Urine } & \text { Total } \\ 10.3 & 10.3 \\ 12.3 & 12.6 \\ 11 \cdot 4 & 12.7 \\ 11 \cdot 7 & 12.6 \\ 0.6 & 0.6\end{array}$

$\begin{gathered}N \\ \text { balance } \\ (\mathrm{g} / \mathrm{d})\end{gathered}$
6.2
4.6
5.0
4.8
0.7

weight $\left(\mathrm{W}^{0.75}\right)$ are given in Table 2 together with the means for live weight and live weight ${ }^{0.75}$. The intended level of infusion was achieved quite closely. Variation in actual intake of energy was caused by variation in the energy excreted via the urine. There were no differences in heat production, nor were there any differences in energy balance which approached significance.

The intakes of energy, heat production and retention of energy $\left(\mathrm{W}^{0.75}\right)$ at twice maintenance energy are given in Table 3. As mentioned before it was not possible to reach the intended energy level on the high acetic acid mixture and the values from that treatment are not strictly comparable as they were obtained at I. 5 times maintenance level of energy. The intakes of energy for the five treatments where the twice maintenance level of energy was achieved were similar. The differences were due to small changes in urinary energy excretion. There were no significant differences in heat production, although the differences between values at 350 and $450 \mathrm{mmol}$ acetic acid/mol VFA and the rest approached significance $(P<0 \cdot I)$. The energy retention of the lambs receiving the mixtures lowest in acetic acid was significantly greater than those receiving the 550,650 and $750 \mathrm{mmol}$ acetic acid.

The intakes of $\mathrm{N}$ and $\mathrm{N}$ balance $\left(\mathrm{g} / \mathrm{W}^{0.75}\right)$ are given in Table 4 , both at energy maintenance and twice maintenance, the differences in retention and intake being entirely due to the excretion via urine. The intended intakes were achieved except as referred to earlier with the diet highest in the proportion of acetic acid, where again values at $\mathrm{I} \cdot 5$ times maintenance energy are given.

Although the lowest acetic acid mixture gave the most positive $\mathrm{N}$ balance at energy maintenance this was not significant; at twice energy maintenance, however, the lambs receiving this treatment had a significantly greater $N$ retention than any of the other treatments. No other differences were significant.

Regression analysis. The differences in utilization of the different VFA mixtures were tested statistically by linear regression analyses of energy retention $(y) v$. ME intake $(x)$, both expressed on a metabolic weight basis. The regression coefficient in this equation is an estimate of $k_{f}$, the efficiency of utilization of ME between maintenance feeding level and twice maintenance, and the value of $x$ when $y=0$ is an estimate of the requirement of ME for maintenance $\left(E_{m}\right)$. Results in Table 5 show that separate estimates of $E_{m}$ for the different mixtures all lay in the range $0.42-0.47 \mathrm{MJ} / \mathrm{kg} \mathrm{W0.75}$ per $\mathrm{d}$, and that the values could be fitted equally well by using a single estimate of $E_{m}$, which was $0.45 \pm 0.02$. The corresponding estimates of $k_{f}$ for the different mixtures, whether with separate or combined estimates of $E_{m}$, were all very similar (approximately $0.6 \mathrm{I}$ ) except for the mixture with the lowest proportion of acetic acid, which had a $k_{f}$ value of 0.78 .

Regression of $\mathrm{N}$ retention $\left(y, \mathrm{~g} / \mathrm{W}^{0.75}\right)$ on energy retention $\left(x, \mathrm{MJ} / \mathrm{W}^{0.75}\right)$ showed that a common regression coefficient $\left(\mathrm{I} \cdot 7 \mathrm{I} \pm 0^{\circ} \mathrm{I} 3\right)$ could be fitted to all the mixtures, but that there 
Table 2. Energy intake, heat production and energy balance for sheep infused with mixtures containing different proportions of volatile fatty acids (VFA) at maintenance energy level

(Each value is the mean of six observations except the first and last treatments which are based on four observations)

\begin{tabular}{ccc} 
Molar proportions (mmol/mol) \\
$\overbrace{\text { Acetic }}^{\text {Propionic }}$ & Butyric \\
350 & 550 & 100 \\
450 & 450 & 100 \\
550 & 350 & 100 \\
650 & 250 & 100 \\
750 & 150 & 100 \\
850 & 50 & 100 \\
\multicolumn{3}{c}{ SE of treatment means }
\end{tabular}

$\begin{array}{cc}\begin{array}{c}\text { Live wt } \\ (\mathrm{kg})\end{array} & \begin{array}{c}\text { Metabolic wt } \\ \left(\mathrm{W}^{0.75}\right)\end{array} \\ 28.6 & \mathrm{I} 2.4 \\ 27.4 & \mathrm{I} 2.0 \\ 28.0 & \mathrm{I} 2 \cdot \mathrm{I} \\ 28.4 & \mathrm{I} 2.3 \\ 29.6 & \mathrm{I} 2.7 \\ 28.4 & \mathrm{I} 2.3 \\ \text { I. I } & 0.4\end{array}$

$\begin{array}{ccc}\text { Entake } & \begin{array}{c}\text { Heat } \\ \text { production }\end{array} & \text { Balance } \\ 446 & 454 & -8 \\ 450 & 433 & \text { I } 7 \\ 445 & 459 & -15 \\ 435 & 451 & -16 \\ 423 & 447 & -23 \\ 438 & 438 & 0 \\ & 17 & \end{array}$

Table 3. Energy intake and energy balance for sheep infused with mixtures containing different proportions of volatile fatty acids (VFA) at twice maintenance energy

(Each value is the mean of six observations except the first and last treatments which are based on four observations)

\begin{tabular}{|c|c|c|c|c|c|c|c|}
\hline \multirow{2}{*}{\multicolumn{3}{|c|}{ Molar proportions $(\mathrm{mmol} / \mathrm{mol})$}} & \multirow{3}{*}{$\begin{array}{l}\text { Live wt } \\
\text { (kg) }\end{array}$} & \multirow{3}{*}{$\begin{array}{c}\text { Metabolic wt } \\
\left(W^{0.75}\right)\end{array}$} & \multicolumn{3}{|c|}{ Energy balance $\left(\mathrm{kJ} / \mathrm{W}^{0.75}\right.$ per $\left.\mathrm{d}\right)$} \\
\hline & & & & & \multirow[b]{2}{*}{ Intake } & \multirow{2}{*}{$\begin{array}{c}\text { Heat } \\
\text { production }\end{array}$} & \multirow[b]{2}{*}{ Balance } \\
\hline Acetic & Propionic & Butyric & & & & & \\
\hline 350 & 550 & 100 & $32 \cdot 6$ & $13 \cdot 6$ & 902 & $55^{\circ}$ & 352 \\
\hline 450 & $45^{\circ}$ & 100 & $27 \cdot 8$ & $12 \cdot 1$ & 902 & 612 & 290 \\
\hline 550 & 350 & 100 & $28 \cdot 4$ & $12 \cdot 2$ & 887 & 638 & 249 \\
\hline 650 & 250 & 100 & $28 \cdot 3$ & $12 \cdot 2$ & 898 & 626 & 272 \\
\hline 750 & I 50 & 100 & $3 I \cdot 0$ & $13 \cdot 1$ & 870 & 615 & 255 \\
\hline \multirow[t]{2}{*}{850} & 50 & 100 & $28 \cdot 7$ & 12.4 & $643^{*}$ & $528 *$ & I I $5^{*}$ \\
\hline & SE of means & & $1 \cdot 4$ & 0.5 & & 30 & 20 \\
\hline
\end{tabular}

Table 4. Nitrogen intake and retention $\left(g / W^{0.75}\right.$ per $\left.d\right)$ for sheep infused with mixtures containing different proportions of volatile fatty acids $(V F A)$ at maintenance and twice maintenance energy infusion

(Each value is the mean of six observations except the first and last which are based on four observations)

\begin{tabular}{ccc} 
Molar proportions (mmol/mol) \\
\hline Acetic & Propionic & Butyrate \\
350 & 550 & 100 \\
450 & 450 & 100 \\
550 & 350 & 100 \\
650 & 250 & 100 \\
750 & 150 & 100 \\
850 & 50 & 100 \\
& SE of means
\end{tabular}

\begin{tabular}{|c|c|}
\hline \multicolumn{2}{|c|}{ Maintenance } \\
\hline $\mathrm{N}$ intake & $N$ retention \\
\hline $0.7 I$ & 0.32 \\
\hline 0.71 & 0.21 \\
\hline 0.72 & 0.19 \\
\hline 0.71 & 0.15 \\
\hline 0.71 & 0.12 \\
\hline 0.71 & 0.05 \\
\hline & 0.05 \\
\hline
\end{tabular}

$\begin{array}{cc}\text { N intake } & \text { N retention } \\ I .42 & I .00 \\ I .43 & 0.73 \\ I .42 & 0.61 \\ I \cdot 42 & 0.73 \\ I \cdot 42 & 0.64 \\ I \cdot 07^{*} & 0.24^{*} \\ & 0.06\end{array}$

* At I.5 times maintenance only; SE not applicable. 
Table 5. Estimates of maintenance requirement $\left(\mathrm{E}_{\mathrm{m}}, M J / d\right.$ per $\left.W^{0.75}\right)$ and of efficiency of utilization of energy above maintenance $\left(\mathrm{k}_{\mathrm{f}}\right)$ derived from regression equations of the form $\mathrm{y}=\mathrm{k}_{1}\left(\mathrm{X}-\mathrm{E}_{\mathrm{m}}\right)$ fitted to measurements of (scaled) metabolizable energy intake $\left(\mathrm{X}, M J / W^{0.65}\right)$ and energy retention $\left(\mathrm{y}, M J / W^{0.75}\right)$

\begin{tabular}{|c|c|c|c|c|c|}
\hline \multirow[b]{2}{*}{ Model } & \multirow{2}{*}{$\begin{array}{l}\text { Acetic acid } \\
(\mathrm{mmol} / \mathrm{mol})\end{array}$} & \multirow[b]{2}{*}{$E_{m}$} & \multicolumn{2}{|c|}{$\underbrace{k_{f}}$} & \multirow{2}{*}{$\begin{array}{l}\text { Residual } \\
\text { SD }\end{array}$} \\
\hline & & & Mean & SE & \\
\hline \multirow{6}{*}{$\begin{array}{l}\text { I. Separate equations for each } \\
\text { mixture }\end{array}$} & 350 & 0.46 & 0.79 & 0.06 & \\
\hline & 450 & 0.42 & 0.61 & 0.04 & \\
\hline & 550 & 0.47 & 0.60 & 0.07 & 0.042 \\
\hline & 650 & 0.46 & 0.63 & 0.06 & \\
\hline & 750 & 0.46 & 0.63 & 0.05 & \\
\hline & 850 & 0.44 & 0.56 & 0.09 & \\
\hline \multirow{6}{*}{$\begin{array}{l}\text { 2. Equations constrained to a } \\
\text { common estimate of } E_{m}\end{array}$} & 350 & & 0.78 & 0.06 & \\
\hline & 450 & & 0.64 & 0.04 & \\
\hline & 550 & 0.45 & 0.57 & 0.04 & $0.04 I$ \\
\hline & 650 & \pm 0.02 & $0.6 I$ & 0.04 & \\
\hline & 750 & & 0.61 & 0.04 & \\
\hline & 850 & & 0.59 & 0.11 & \\
\hline $\begin{array}{l}\text { 3. A single equation fitted to all } \\
\text { values* }\end{array}$ & - & 0.45 & 0.63 & 0.02 & 0.044 \\
\hline
\end{tabular}

were significant differences in intercepts $(P<0.01)$, which were $0.37,0.20,0.20,0.22,0.19$ and 0.05 respectively for the six mixtures in ascending order of acetic acid content. The standard error of the differences in the intercepts was \pm 0.07 , showing that the first of these mixtures gave a significantly higher $\mathrm{N}$ retention at zero energy balance than did the others, but that above maintenance $\mathrm{N}$ retention on all the mixtures increased by $\mathrm{I} \cdot 7 \mathrm{I} \mathrm{g} / \mathrm{MJ}$ increase in energy balance.

\section{DISCUSSION}

The experiments described here were designed to assess the efficiency of VFA utilization in such a manner that the results could be interpreted in absolute terms and not be confounded by uncertainties as to the digestion and metabolism of a basal diet. In this respect the experiment was considered to be successful. There were relatively few mishaps and the sheep appeared to metabolize all the mixtures well with the single exception that the twice maintenance level could not be achieved on the highest acetic acid mixture (850,50, 100).

\section{Utilization of VFA for energy maintenance}

The calorimetric efficiency of utilization of nutrient energy for maintenance (zero energy balance) cannot be calculated directly since measurements were not made of fasting metabolism. However, a mean value of $450 \mathrm{~kJ} / \mathrm{W}^{0.75}$ was obtained for the requirement of energy for maintenance which is similar to that of $4 \mathrm{I} 8 \mathrm{~kJ} / \mathrm{W}^{0.75}$ derived from a large comparative slaughter experiment with similar lambs given concentrate diets (Ørskov \& McDonald, 1970). It is considerably higher than values for maintenance obtained with mature sheep derived from fasting metabolism (Armstrong \& Blaxter, 1957a), and higher than the values recommended by the Agricultural Research Council (I965), but similar to values obtained for the milk-fed lambs (Walker \& Jagusch, 1970). Moreover, the similarity of the values obtained for heat production at zero energy balance indicates strongly that there were no differences in efficiency of utilization of the large range of mixtures of VFA infused below maintenance. This observation essentially agrees with the conclusion of 
Armstrong \& Blaxter (1957a) that mixtures of acetic, propionic and butyric acid varying in molar proportions from $0,600,400$ to $900,60,40$ respectively were utilized with virtual constant efficiency for maintenance. The observation also supports theoretical calculations of the amount of glucose precursors, in this instance propionic acid and some glucogenic amino acids, required to sustain an efficient oxidation of acetyl $C o A$ via the citric acid cycle. Hovell (1972) calculated that about I mol propionic acid was required for efficient oxidation of $16 \mathrm{~mol}$ acetyl CoA. The $\mathrm{N}$ retention at energy maintenance was significantly greater for the mixture containing the highest level of propionic acid but did not differ between the other mixtures. This agrees with observations by Armstrong \& Blaxter (1957 $b$ ). The finding is of little practical significance since it is most unlikely that normal rumen fermentation could yield such a high proportion of propionic acid (Ørskov, 1975). Nevertheless the observation suggests that propionate, acting as a carbohydrate precursor, was having a sparing effect on protein metabolism, an effect which has been reported for non-ruminants (see Munro, 1964).

\section{Utilization of $V F A$ for energy retention}

With the single exception of the infusate highest in propionic acid, there were no significant differences in the utilization of the other VFA mixtures for energy retention. In this respect the results agree with the observations summarized by Orskov \& Allen (1966), who concluded that differences in ME for practical diets could not be explained by differences in utilization of VFA. The results also confirm the conclusions reached by Bull et al. (I970) with sheep and Ørskov et al. (1968) with dairy cows.

The results do not, at first, appear to agree with the original conclusion of Armstrong \& Blaxter (1957b) and Armstrong et al. (1958), namely that the VFA differ markedly in the efficiency with which they can promote energy gain. Table 6 lists the individual mixtures of VFA infused in the current experiment, together with the energy values per mol for each VFA. Using the values presented, the contributions of the different VFA to the energy in the mixture were then calculated. The values obtained by Armstrong \& Blaxter (1957 $b$ ) for the efficiency of utilization above maintenance $\left(k_{f}\right)$ for the individual acids were then used to predict $k_{f}$ for the different mixtures used in the present experiment not as originally expressed by Armstrong et al. (1958) but recalculated to account for the contribution of each individual VFA to the energy value of the mixtures. Within the range of VFA proportions likely to occur on fermentation of rormal diets, namely $450-750 \mathrm{mmol} /$ acetate $\mathrm{mol}$, the $k_{f}$ predicted from the results of Armstrong \& Blaxter (1957 b) varies only from 0.44 to 0.50 , a difference too small to be detected with statistical significance. When mixtures containing $450-750 \mathrm{mmol} /$ acetate $\mathrm{mol}$ were infused in the present experiment, values ottained for $k_{f}$ ranged from 0.57 to 0.64 . The absolute values differ markedly from those obtained by Armstrong \& Blaxter (I957 $b$ ) but the extent to which $k_{f}$ is affected by the proportion of acetate in the mixture is, in both instances, too small to be of practical importance.

The absolute values of $k_{f}$ in the experiment here were higher than those of Armstrong \& Blaxter (1957b) and Armstrong et al. (1958), but similar to the values found by Hovell et al. (1976). The differences cannot be attributed to other components of the heat increment, e.g. work of digestion (see Webster, 1978) since the heat increments reported by Armstrong et al. (1958) were determined when the VFA were infused as an increment to a basal hay diet. The slopes, of course, depend on the value for zero energy retention. If a value of $400 \mathrm{~kJ} / \mathrm{W}^{0.75}$ was used the slopes were $0.69,0.58,0.5 \mathrm{I}, 0.55,0.54$ and 0.46 , but when this value was used the residual standard deviation increased.

The very small effect on $k_{f}$ of differences in molar proportions of acetate varying from $45^{\circ}$ to $750 \mathrm{mmol} / \mathrm{mol}$ indicates very strongly that differences between normal feeds in the 
Table 6. Calculation of mixtures used in the present experiment in terms of their energy proportions and predictions of the efficiency of utilization $\left(k_{f}\right)$ using the values measured by Armstrong \& Blaxter (1957b)

\begin{tabular}{|c|c|c|c|c|c|c|c|}
\hline \multirow{4}{*}{$\begin{array}{l}\text { Acetic acid } \\
\text { Propionic acid } \\
\text { Butyric acid }\end{array}$} & \multicolumn{4}{|c|}{ Molar proportions (mmol $/ \mathrm{mol}$ ) } & \multicolumn{3}{|r|}{$\begin{array}{c}\text { Energy } \\
(\mathrm{kJ} / \mathrm{mol})\end{array}$} \\
\hline & 350 & 450 & 550 & 650 & 750 & 850 & 874 \\
\hline & 550 & 450 & 350 & 250 & 150 & 50 & 1534 \\
\hline & 100 & 100 & 100 & 100 & 100 & 100 & 2190 \\
\hline \multicolumn{7}{|c|}{ Energy proportions $(\mathrm{kJ} / \mathrm{MJ})$} & $k_{f}^{*}$ \\
\hline Acetic acid & 220 & 300 & 390 & 480 & 590 & 720 & $0.329 \pm 0.026$ \\
\hline Propionic acid & 620 & 530 & 430 & 330 & 210 & 70 & $0.563 \pm 0.032$ \\
\hline Butyric acid & 160 & 170 & 180 & 190 & 200 & 210 & $0.619 \pm 0.026$ \\
\hline $\begin{array}{l}\text { Predicted } k_{f} \\
\text { (Armstrong \& Blaxter, } \\
1957 b \text { ) }\end{array}$ & 0.52 & 0.50 & 0.48 & 0.46 & 0.44 & 0.41 & \\
\hline $\begin{array}{l}\text { Observed by Armstrong } \\
\text { et al. (1958) }\end{array}$ & \multicolumn{7}{|c|}{$0.32 \pm 0.018$} \\
\hline Present results & $\begin{array}{c}0.78 \\
\pm 0.050\end{array}$ & $\begin{array}{c}0.64 \\
\pm 0.040\end{array}$ & $\begin{array}{r}0.57 \\
\pm 0.04\end{array}$ & $\begin{array}{r}0.61 \\
\pm 0.04\end{array}$ & $\begin{array}{r}0.61 \\
\pm 0.04\end{array}$ & $\begin{array}{c}0.59 \\
\pm 0.100\end{array}$ & \\
\hline
\end{tabular}

efficiency with which they are used to promote growth and fattening cannot be attributed to different efficiencies of utilization of the different VFA above maintenance. This conclusion applies even if the original values of Armstrong \& Blaxter (1957b) for the heat increments of the individual VFA are precisely correct. However, the discrepancy between the observed (0.32, Armstrong et al. 1958) and the recalculated values for $k_{f}$ presented here (0.44) for a mixture containing $750 \mathrm{mmol}$ acetate/mol (see Table 6) suggests that some of the values obtained may have been confounded, as originally suggested by Armstrong et al. (1958) by uncertainties as to the metabolism of the basal diet. The conclusion from the present experiment in which sheep were sustained entirely by infusion, namely that differences in the proportions of VFA absorbed by sheep do not markedly influence the efficiency of utilization of energy above maintenance is in agreement with observations on pelleted roughages (Blaxter \& Boyne, 1978). However, for mixed feeds and long hay, etc. Blaxter \& Boyne (1978) showed that the efficiency of utilization of ME is proportional to metabolizability, and at constant metabolizability the utilization decreases with increasing fibre content. It would not be possible to explain these differences in terms of the molar proportions of VFA yielded by rumen fermentation. For this class of feeds, therefore, an alternative explanation to the VFA hypothesis must be sought to explain differences in the efficiency with which these feeds can promote body gain. In the analysis by Blaxter \& Boyne (1978) there was a positive effect of protein content on utilization of ME above maintenance which may have some bearing on contribution of glucose precursors. This positive effect of protein was not observed below the maintenance energy level.

$$
\text { Ratio, } C_{2}: C_{3} \text { units }
$$

Effects on energy metabolism of the large range of $\mathrm{C}_{2}: \mathrm{C}_{3} \mathrm{C}$ units used in the present experiment reveal some insight as to the requirement of sheep for glucose precursors for oxidation and synthesis. The requirement for oxaloacetic acid to complete the oxidation of acetyl CoA through the citric acid cycle is difficult to assess as there is, at least theoretically, complete regeneration of oxaloacetate. At the maintenance energy level none of the mixtures infused here appeared to cause any unusual patterns of heat production or in the urinary excretion 
of metabolites. However, problems of metabolism were apparent whenever an attempt was made to increase the level of infusion of the highest acetic acid mixture to more than approximately $\mathbf{I} \cdot 5$ times maintenance. Hovell (1972) calculated that a minimum ratio, I mol propionic acid/4. $\mathrm{I}$ mol acetic acid was required for the synthesis of sufficient glucose to generate the NADPH required for lipid synthesis via the pentose phosphate pathway. By this criterion the highest acetic acid mixture was markedly deficient in NADPH precursors. It is possible that the low amount of propionate relative to acetate required for maintenance, together with some glucose precursors from casein, allowed the sheep to sustain a certain amount of synthesis before glucose precursors became limiting. The reason why it was possible to reach $850 \mathrm{mmol} / \mathrm{mol}$ with relatively little problem may well be due to the fact that casein was infused as well which could provide a source of glucose precursors. It is perhaps also relevant that the urinary excretion of $\mathrm{N}$ at maintenance was greatest with the mixture containing $850 \mathrm{mmol} / \mathrm{mol}$ acetic acid. When the infusion exceeded this point it appeared that the sheep were not able to respond to a relative excess of $\mathrm{C}_{2}$ units by increasing heat production as suggested by Hovell (I972). While one can only speculate on this point, the results do suggest that if a normal diet gave VFA proportions in which the molar ratio, acetic acid:propionic acid exceeded $4: 1$, then sheep would have no alternative but to limit their intake to that which could be metabolized at normal energetic efficiency.

The authors are very grateful to Mr I. McDonald for his help and suggestions in the design of the experiments and in the statistical analysis of the results.

\section{REFERENCES}

Agricultural Research Council (1965). The Nutrient Requirements of Farm Livestock, No. 2, Ruminants. London: H.M. Stationery Office.

Annison, E. F. \& Armstrong, D. G. (1970). In Physiology of Digestion and Metabolism in the Ruminant, p. 422 [A. T. Phillipson, editor]. Newcastle-upon-Tyne: Oriel Press.

Armstrong, D. G. \& Blaxter, K. L. (I957a). Br. J. Nutr. II, 247.

Armstrong, D. G. \& Blaxter, K. L. (1957b). Br. J. Nutr. I1, 413.

Armstrong, D. G., Blaxter, K. L. \& Graham, N. McC. (1957). Br. J. Nutr. 11, 392.

Armstrong, D. G., Blaxter, K. L., Wainman, F. W. \& Graham, N. McC. (1958). Br. J. Nutr. 12, 177.

Barcroft, J., McAnnally, R. A. \& Phillipson, A. T. (1944). J. exp. Biol. 20 , 120.

Blaxter, K. L. (1962). Energy Metabolism in Ruminants. London: Hutchinson \& Co. Ltd.

Blaxter, K. L. \& Boyne, A. W. (1978). J. agric. Sci., Camb. 9o, 47.

Bull, L. S., Reid, J. T. \& Johnson, D. E. (1970). J. Nutr. 100, 262.

Daccord, R. (1971). Effect of supplement of hay and concentrate on energy metabolism in sheep. Thesis Ecole Polytechnique Federale, Zurich, Switzerland.

Holter, J. B., Heald, C. W. \& Colovos, N. F. (1970). J. Dairy Sci. 53, I 241.

Hovell, F. D. (1972). The utilization of salts of volatile fatty acids by growing lambs. PhD Thesis, University of Aberdeen.

Hovell, F. D. \& Greenhalgh, J. F. D. (1978). Br. J. Nutr. 40, I7I.

Hovell, F. D., Greenhalgh, J. F. D. \& Wainman, F. W. (1976), Br. J. Nutr. 35, 343.

Lawrence, P. R. \& Thomas, P. C. (1973). Anim. Prod. 17, 209.

Munro, H. N. (1964). In Mammalian Protein Metabolism, vol. I, p. 38I [H. N. Munro and J. B. Allison, editors]. London: Academic Press.

Ørskov, E. R. (1965). The utilization of volatile fatty acids by growing lambs. PhD Thesis, University of Reading.

Ørskov, E. R. (1975). Wld Rev. Nutr. Diet, 22, I 52.

Ørskov, E. R. (1977). Wld Rev. Nutr. Diet, 26, 225.

Ørskov, E. R. \& Allen, D. M. (1966). Br. J. Nutr. 20, 519.

Ørskov, E. R., Flatt, W. P., Moe, P. V., Munson, A. W., Hempken, R. W. \& Katz, I. (I968). Br..J. Nutr. 23, 443.

Ørskov, E. R. \& Grubb, D. A. (1977). Proc. Nutr. Soc. 36, 128 A.

Ørskov, E. R., Grubb, D. A., Webster, A. J. F. \& Smith, J. S. (1978). Proc. Nutr. Soc. 37, 5 IA.

Ørskov, E. R., Grubb, D. A., Wenham, G. \& Corrigal, W. (1979). Br. J. Nutr. 41, 553.

Ørskov, E. R. \& McDonald, I. (1970). In Energy Metabolism of Farm Animals [A. Schurch and C. Wenk, editors]. Zurich: Juris Druck Verlag. 
Tyrrell, H. F., Reynolds, P. J. \& Moe, P. W. (1975). J. Anim. Sci. 41, 423.

Wainman, F. W. \& Blaxter, K. L. (1969). In Energy Metabolism of Farm Animals [K. L. Blaxter, J. Kielanowski and G. Thorbek, editors]. Newcastle-upon-Tyne: Oriel Press Ltd.

Walker, D. M. \& Jagusch, K. T. (1970). In Energy Metabolism of Farm Animals [A. Schurch and C. Wenk, editors]. Zurich: Juris Druck Verlag.

Webster, A. J. F. (1978). Wld Rev. Nutr. Diet. (In the Press.) 